\title{
Lower Eocene Ostracods from the Rusayl Shale Formation of Oman
}

\author{
MICHAEL C. KEEN ${ }^{1}$ and ANDREW RACEY ${ }^{2}$ \\ 'Dept of Geology and Applied Geology, University of Glasgow, Glasgow G12 8QQ, U.K. \\ ${ }^{2}$ The Geochem Group, Chester Street, Chester CH4 8RD, U.K.
}

\begin{abstract}
A small fauna of ostracods is described from the Early Eocene of the Rusayl Shale of northern Oman. The fauna is dominated by Neocyprideis rusaylensis sp. nov., forming $95 \%$ of the ostracods. The other species present are Stigmatocythere siddiquii sp. nov., Krithe sp. and Paracypris sp. None of these taxa has been previously recorded, but there is a close resemblance to the fauna described from the upper part of the Lower Eocene of Pakistan. The fauna indicates restricted conditions, probably of fluctuating salinities in coastal lagoons, which were often hypersaline.
\end{abstract}

\section{INTRODUCION}

During studies on the Palaeogene of northern Oman, one of us (A.R.) discovered a small ostracod fauna from the lower member of the Rusayl Shale Formation. The fauna came from shales underlying a thin limestone (middle member) which has yielded a larger foraminiferal fauna of early to mid Early Eocene age. The shales have also been provisionally dated as Ypresian on the basis of miospores. The Rusayl Shale is broadly equivalent to the more evaporitic Rus Formation of the Arabian Peninsula. Four species of ostracods have been discovered, two of which are described here. All of the specimens come from a single horizon which outcrops in an extensive road cutting near the village of Al Khawd to the west of Muscat (Fig. 1). The ostracods are dominated by Neocyprideis rusaylensis sp. nov., which forms $95 \%$ of the fauna. Neocyprideis is an extinct genus, but is closely related to the living Cyprideis which is the typical brackish or hypersaline ostracod of the present day. Neocyprideis has been interpreted as inhabiting a variety of low or high salinity environments (Keen, 1977, 1990). The other significant species is Stigmatocythere siddiquii sp. nov., which is very similar to A. obliqua Siddiqui 1971, described from the Shales with Alabaster of Pakistan which are dated as late Early Eocene. Stigmatocythere is also recorded in association with Neocyprideis in Pakistan (Siddiqui 1971), lending credence to the idea of a restricted marine fauna present in the eastern Tethys. However, Stigmatocythere, unlike Neocyprideis, is also commonly found in normal shallow marine faunas. The other two genera present, represented by Krithe sp. and Paracypris sp. are usually considered to be marine taxa. No ostracods have been described so far from the Palaeogene of Oman, and few works have been published on the Tertiary of the Arabian Peninsula. Al Furaih has published several papers dealing with late Cretaceous and early Tertiary ostracod faunas from NE Saudi Arabia (e.g. 1980), but these rich marine faunas have nothing in common with the fauna described here, probably due to differing age and palaeoenvironment. The biogeographical implications of this fauna from Oman are of interest in reinforcing the concept of an eastern Tethyan ostracod fauna.

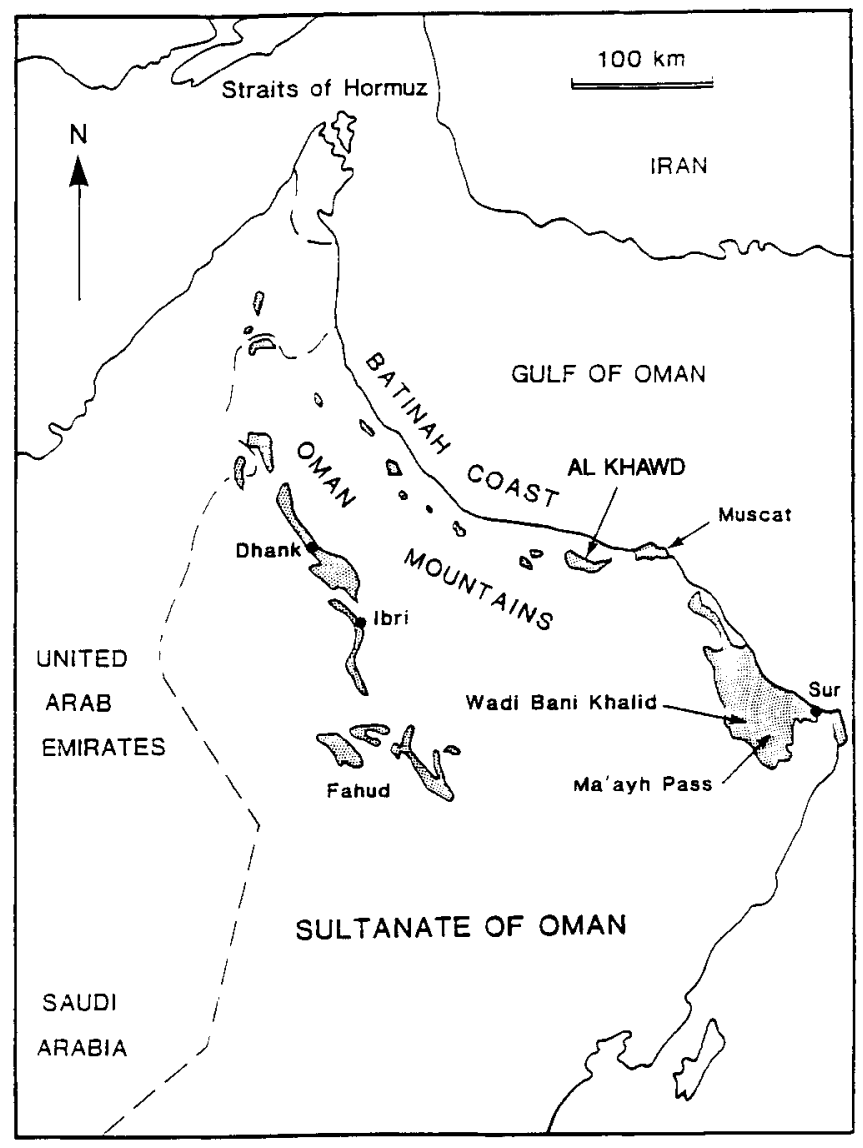

Fig 1. Extent of the Tertiary outcrop (stippled) in northern Oman, with the position of Al Khawd indicated. 


\section{RUSAYL SHALE FORMATION}

This formation consists of a dominantly regressive sequence and is divisible into three members:-

(i) a lower member ( $30 \mathrm{~m}$ thick) which has as its base a laterally discontinuous basal ferruginous limestone-chert conglomerate developed above a sedimentary hiatus. (This hiatus is also recognisable in the western Oman mountains near Ibri where the top of the underlying Jafnayn Formation is pitted due to incipient karstic weathering). This is overlain by a $5 \mathrm{~m}$ thick unit of graded and lowangle cross-bedded calcarenite containing a microfauna of textulariids, miliolids and calcareous green algae (including $O$ vulites morelleti Elliot, Ovulites maillolensis, Furcoporella diplora and Neomeris sp.), interpreted as a storm sheet. Overlying these is a sequence of yellow marly limestones and yellow, green and purple (grey where unweathered) marls, often rich in gastropods (including Faunas vulcanicus Schlotheim, Potamides cf. pascoei Cox, Pseudobellardia cf. pireniformis and Megalytolus sp.), bivalves (including $O$ strea sp., Chama sp., Cardiaceae, Luniaceae and Tellidinidae), occasional floods of cytherid ostracods (the main subject of this paper) and rare echinoids (including Schizaster sp. and Linthia sp.). The marls commonly contain gypsum veins and box-works (originally anhydrite). This unit is interpreted as representing a restricted supratidal to lagoonal environment. Occasional laterally persistent oyster rudstone beds within these marls towards the top of the member formed within this lagoon.

(ii) a middle member ( $5 \mathrm{~m}$ thick) which comprises two units, the lower of which consists of interbedded massive peloidal wackestones and finely laminated algal bindstones. The peloidal wackestones contain rare miliolids, indeterminate calcareous green algae and rare echinoids (Echinocyamus sp. and ?Petallobrissus sp.) and are interpreted as representing a normal shallow marine inner shelf (tidal flat?) environment. The finely laminated beds contain miliolids (Triloculina) and rare, poorly preserved peneroplids, bound together by strongly recrystallised algae. Many tiny filaments are also present; these are too fine to be algal but may be the bi-product of algal decay by bacterial action. These laminated beds were deposited in a shallow restricted (?hypersaline), possibly low intertidal environment. The upper unit consists of cross-bedded bioclastic wackestones-packstones rich in foraminifera (notably Alveolina agerensis White pers. comm; Somalina sp.1, Opertobitolites sp. 1, indicative of a Lower Eocene age, and miliolids), calcareous green algae [including the codiacean Ovulites maillolensis and the dasycladaceans Furcoporella diplora, Trinocladus perplexus and Cympolia elongata (Defrance)] and rare fibulariid echinoid fragments. T. perplexus and C. elongata indicate a Palaeocene to Lower Eocene age. These are interpreted as having been deposited in shallow (3-10m), normal marine, inner shelf shoals. These units may represent a minor transgressive sequence whereby normal marine, inner shelf shoals transgress shallower, more restricted "tidal flat" sediments.

(iii) an upper member ( $80 \mathrm{~m}$ thick: thickness is highly variable due to compaction of marly interbeds during folding) which contains wellsorted, often graded and low-angle cross-bedded quartz sandstones, often with bi-directional palaeocurrents. These are interpreted as representing shallow, high energy, tidal and/or storm influenced barrier facies. Marl interbeds, often gypsiferous, also occur above and below these sandstone beds and oyster rudstones are not uncommon. The marls contain a mollusc and gastropod fauna similar to that of the lower member, together with rare echinolampadid echinoids and were

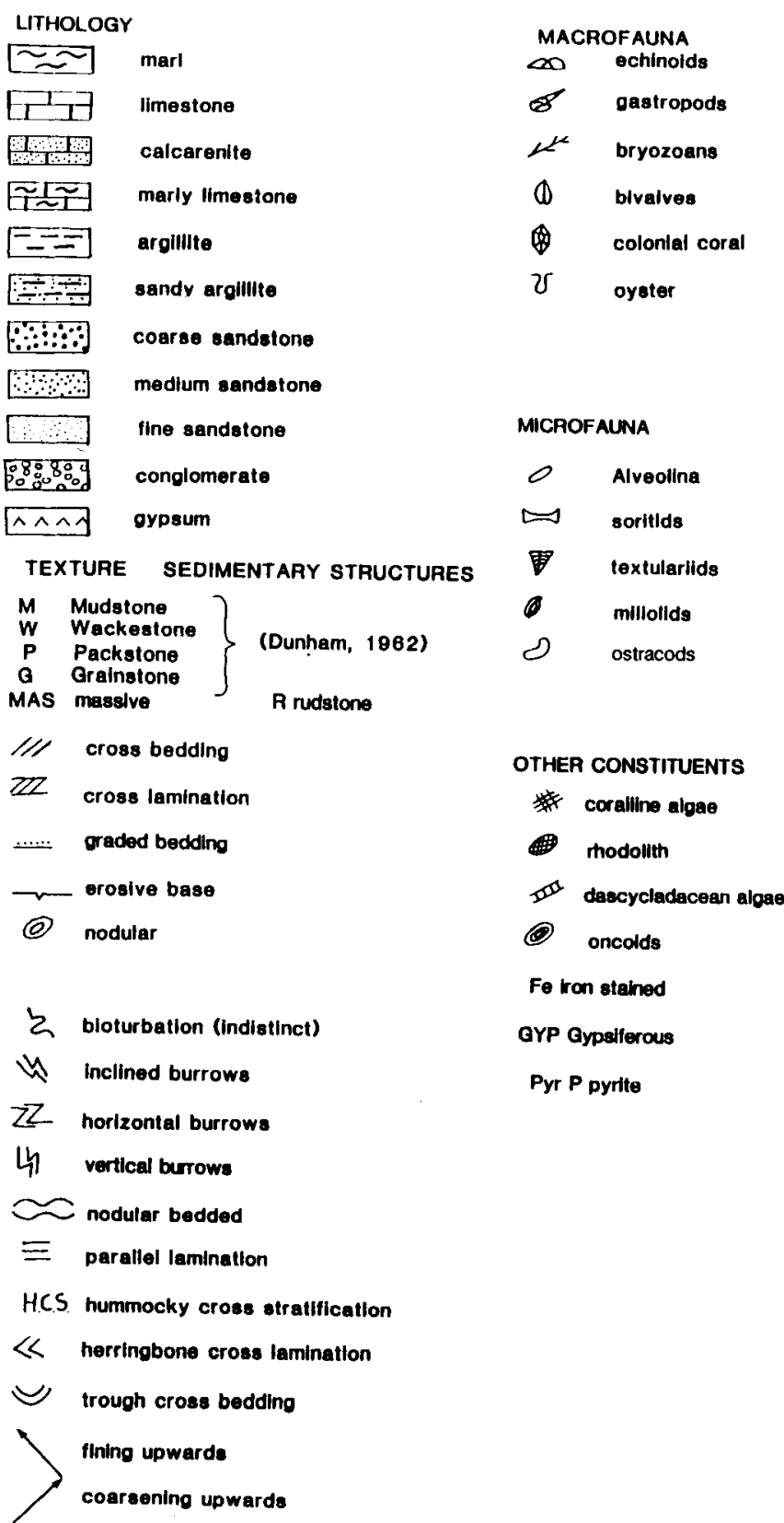

Fig 2. Key to log of Rusayl Shale Formation of Fig 3.

deposited in a quiet, shallow, restricted inner shelf environment. Towards the top of this unit, indurated marls have yielded a microfauna of Alveolina sp., Linderina rajasthanensis, Somalina stephaninii Silvestri, Somalina sp. 1, Orbitolites sp., miliolids and textularids, indicative of a shallow, low energy, slightly deeper marine environment. This marks the beginning of the transgression which is best seen in the overlying Seeb Limestone Formation.

The Russayl Shale Formation is dated here as Early to Mid Eocene. Larger foraminiferal faunas are, however, poorly developed owing to the regressive facies. Since the base of the formation has not been dated due to the absence of larger foraminifera, it has not been possible to determine whether the sharp lithological change at the 

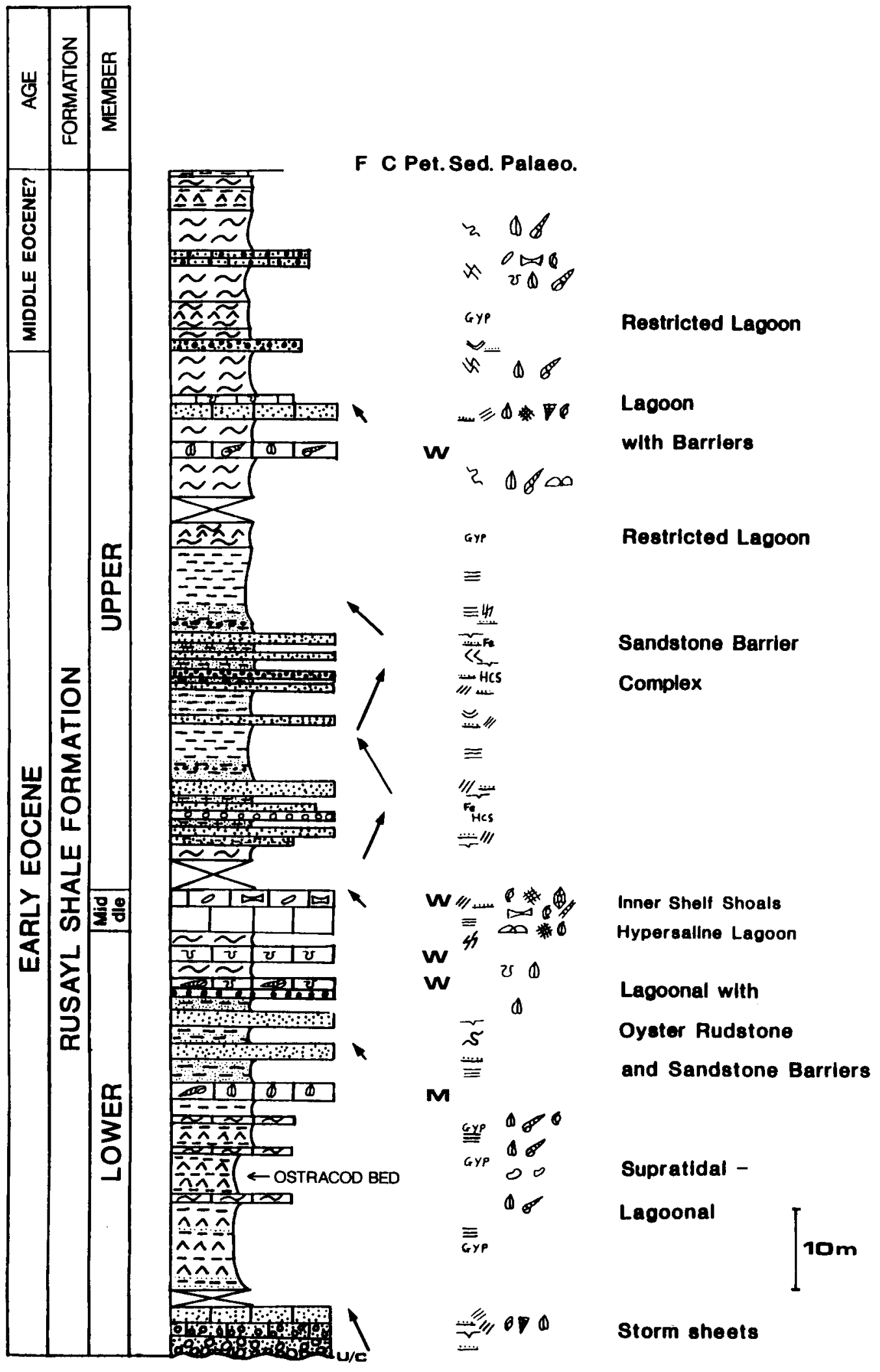

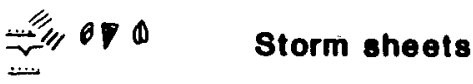

Fig 3. Representative log of the Rusayl Shale Formation. For key, see Fig. 2 opposite. 
boundary with the underlying Jafnayn Formation also marks a stratigraphical break. It does however, indicate a sedimentary facies hiatus. Of the three taxa occurring in the oldest larger foraminiferalbearing beds i.e. from the middle member, two (Somalina nov. sp.1 and Opertorbitolites nov. sp. 1) are new and the third (Alveolina agarensis) although known from the Lower Eocene (Gaemers, 1978) ranges, together with Somaline nov. sp.1, into the Middle Eocene in Oman (White pers. comm.). The upper part of this formation is provisionally dated as Middle Eocene on the presence of Linderina rajasthanensis, a species not yet known from older strata.

\section{SYSTEMATIC DESCRIPTIONS}

The specimens are deposited in the Natural History Museum, London. Measurements are in microns.

Subclass Ostracoda Latreille, 1806

Order Podocopida Muller, 1894

Suborder Podocopina Sars, 1866

Superfamily Cypridacea Baird, 1845

Family Paracyprididae Sars, 1923

Genus Paracypris Sars, 1923

Paracypris sp.

(Pl. 1, fig. 6)

Material: 10 specimens; OS 13928

Dimensions: L 670, H 280

Remarks: The material consists of carapaces only, so it has not been possible to examine the internal details. For this reason it is difficult to determine the species. It shows some similarity to Paracypris nigeriensis Reyment 1960, which has been recorded from the Maastrichtian to Palaeocene of Nigeria (Reyment 1960) and the Early Eocene of Egypt (Bassiouni \& Luger 1990). The species recorded here differs from $P$. nigeriensis in being smaller and in having a lower, less arched, dorsal margin.

Superfamily Cytheracea Baird, 1850

Family Cytherideidae Sars, 1925

Subfamily Cytherideinae Sars, 1925

Genus Neocyprideis Apostolescu, 1956

Neocyprideis rusaylensis sp. nov.

(Pl. 1 figs 7-15)

Derivation of name: After the Rusayl Shale Formation

Diagnosis: A species of Neocyprideis showing sexual dimorphism, female left valve with rounded poster-ventral margin, highest point towards posterior, 60-65 normal pore canals.
Holotype: Female carapace, OS 13929

Material: Numerous, catalogued specimens, OS 13930 - 13938

Locality and Horizon: Lower member of Rusayl Shale Formation, Al Khawd road cutting, northern Oman.

Description: The carapace is of normal size for the genus. Sexual dimorphism is well developed; in lateral view the males are more elongate, have a more broadly rounded posterior margin, and have straighter, more nearly parallel dorsal and ventral margins. The ventral margin of the female left valve has a slight anterior concavity with a strongly arched posterior half. The male left valve has a more pointed postero-dorsal angle. In both sexes the highest point of the left valve is near the posterior; in the right valve the dorsal margin is more curved, with its highest point, although still in the posterior half, more centrally placed. In dorsal view sexual dimorphism is prominent; the female has a swollen posterior, probably indicating the presence of a brood pouch. Larval stages, as is usual for the genus, have a different lateral outline from the adult, with the highest point towards the anterior, more strongly so in the right valve. A weak vertical-descending dorsal sulcus is present about a quarter of the way along the dorsal margin from the anterior. The surface of the carapace is predominantly smooth in the adult, although weak punctae may be present along the ventral margin and in the centro-dorsal area (see Pl.1 figs 7, 9, 11). Larval stages have strongly developed punctae (Pl. 1 figs 10,12 ). No adults have been observed with tubercles, but all the larval specimens are tuberculate; two prominent tubercles are present in the posterior half of the carapace (Pl. 1 figs 10,12 ). The normal pore canals are often prominent, and are 60-65 in number. They are of sieve-type, and are of various shapes; the commonest outline is circular (Pl. 1 fig. 13) but irregular shapes are also frequently present (Pl. 1 fig. 15 ).

No internal details have been observed because all the material consists of carapaces.

Dimensions:
Female left

L

Male left

Male right

$760-850$

$770-850$

850
H

$540-560$

470-520

520
$\mathbf{L} / \mathbf{H}$

1.48

1.64

1.63
Female width (from Pl.1 fig. 9), 430

Male width (from Pl.1 fig. 14), 370

Remarks: The generic designation of this species is based on the lateral outline as no internal details have been observed. The lateral outline of the male is similar to that of several described species such as $N$. colwellensis (Jones 1857) and $N$. williamsoniana (Bosquet 1852) from the late Eocene and Oligocene of NW Europe, but the outline of

\section{Explanation of Plate 1}

All specimens from the lower member of the Rusayl Shale from the Al Khawd road cutting. All are carapaces; all measurements in microns; specimens deposited in the Natural History Museum, London.

Figs $1-3,5$

Fig. 4.

Fig. 6.

Figs 7-15
Stigmatocythere siddiquii sp. nov.; Fig. 1, Holotype, OS 13939, left view female L= 560, x90; Fig. 2, left view male, OS 13940, L=540 x93; Fig. 3a, b, Os 13941, stereo pair, female right view, $L=560$, x90; Fig. 5, Os 13939, female ventral view, $L=550, x 91$.

Krithe sp., right view, $L=740$, x68; OS 13942.

Paracypris sp., right view, $\mathrm{L}=670, \mathrm{x} 75$; OS 13928

Neocyprideis rusaylensis sp. nov. Fig. 7, Holotype, OS13929, left view female, L =800, x63; Fig.8, left view male, OS 13930, L=770, x65; Fig. 9, female dorsal view, OS $13931, L=770$, x65; Fig. 10, larval stage 6 right view, OS 13932, $\mathrm{L}=410$, x122; Fig. 11, male right view, OS 13933, L =850, x59; Fig. 12, larval stage 6 left view, OS 13934, L =410, x122; Figs 13, 15, sieve-type normal pore canals (from specimen, Fig. 11), scale bar - 10m; Fig. 13 is a circular pore, Fig. 15 an irregular pore; Fig. 14, male dorsal view, OS 13935, L= 820, x60. 


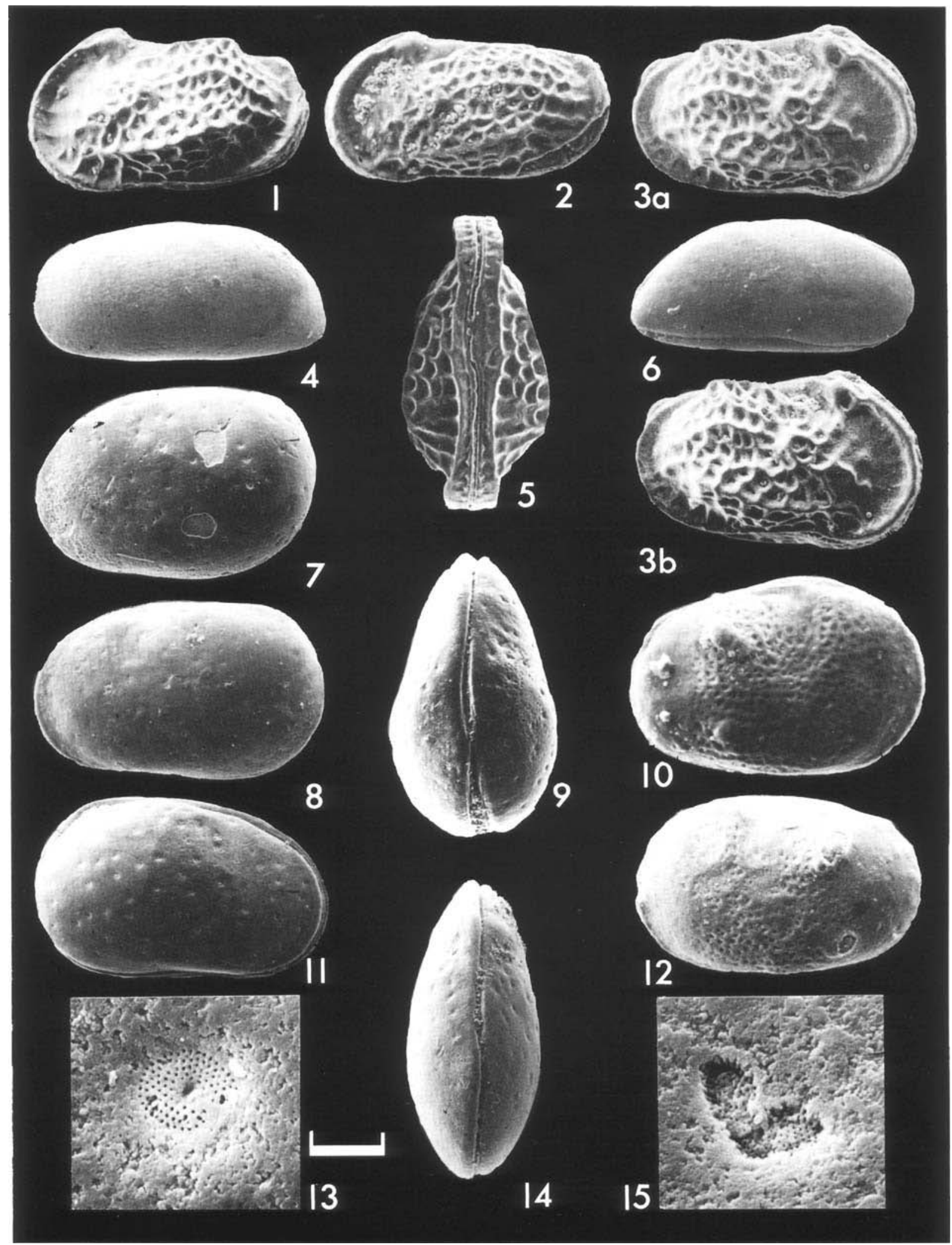


the female is quite distinctive and unlike any described species, especially the arched posterior part of the ventral margin. N. grandinatus Tambareau 1972 from the Palaeocene of southern France has the closest lateral outline to the female of $N$. rusaylensis, but the male is much larger and much more elongate. Species of Neocyprideis can be separated on the basis of the number of radial pore canals (Keen, 1990), but this feature cannot be examined. However, $N$. rusaylensis does have more numerous normal pore canals than other species; the norm is for 45-55, compared with the 60-65 recorded here (see also the palaeoecology section below).

No species have been described so far from the Palaeogene of the Middle East; Siddiqui (1971) has recorded the genus from the Eocene of Pakistan.

Subfamily Krithinae Mandelstam in Bubikan, 1958

Genus Krithe Brady, Crosskey \& Robertson, 1874

Krithe sp.

(Pl. 1, fig. 4)

Material: 3 specimens; OS 13942

Dimensions: L 670, H 340

Remarks: The generic determination has been based on the lateral outline, which is typical of most species of Krithe. The dorsal margin is less curved than in many species, tending towards being parallel to the ventral margin, and in this respect differs from other species described from North Africa and the Middle East. The specimens are very similar to $K$. oryza Neal \& Singh 1984 from the Middle Eocene of Assam.

Family Trachyleberididae

Genus Stigmatocythere Siddiqui 1971

Stigmatocythere siddiquii sp. nov.

$$
\text { (Pl. 1, figs 1-3, 5) }
$$

Derivation of name: After Quadeer Siddiqui, the author of the genus Stigmatocythere.

Diagnosis: A species of Stigmatocythere with arched dorsal ridge, strong reticulation between ridges, smooth anterior and posterior areas, and a knob-like subcentral tubercle.

Holotype: Female carapace, OS 13939

Locality and Horizon: Lower member of Rusayl Shale Formation, $\mathrm{Al}$ Khawd road cutting Northern Oman.

Material: 17 specimens, OS 1340, OS 1341.

Description: Sexual dimorphism is prominent, with smaller and more elongate males. The dorsal margin, especially of the female, is overreached by the dorsal ridge in lateral view; the highest point is at the eye-tubercle; the anterior margin is obliquely rounded and bears some 16 poorly preserved denticles; left valve overlaps right valve at the antero-dorsal and postero-dorsal angles.

The ornamentation is strongly developed, and consists of three longitudinal ridges with reticulation between them. The dorsal ridge starts at the anterior, level with the subcentral tubercle, is strongly arched upwards over the dorsal margin, finishing near the posterodorsal angle. The median ridge runs from the subcentral tubercle, is curved upwards, finishing near the posterior margin. The ventral ridge is the strongest of the three; it joins the anterior marginal rim via a strong reticulation mesh, curves upwards away from the ventral margin, finishing amongst the reticulation meshes at the posterior of the carapace. A curved ridglet joins the eye tubercle with the subcentral tubercle. The subcentral tubercle is well defined, is knob-like, bearing three reticulation meshes. The anterior marginal rim is prominent on the right valve, less so on the left. The reticulation developed between the longitudinal ridges is even, with four rows between the ventral and median ridges and three between the median and dorsal ridges. The anterior part of the carapace is almost smooth, although "ghost" reticulation can be observed; two pore cones are prominent in this area, the upper cone being "alpha", the lower being "beta" under the terminology developed by Benson (1972); the beta pore cone lies at the end of a ridglet running from the subcentral tubercle. Another, smaller, smooth area is developed at the posterior. Pore cones can be seen on the lateral surface.

$\begin{array}{lllll}\text { Dimensions: } & \text { L } & \text { H } & \text { L/H } & \text { W } \\ \text { Female Car. OS13939 } & 560 & 330 & 1.70 & 280 \\ \text { Male Car. OS13940 } & 540 & 280 & 1.93 & \end{array}$

Remarks: The most similar species described so far is $S$. obliqua Siddiqui 1971, from the Lower Eocene Shales with Alabaster of the Rakhi Nala, Pakistan, which is the type species of the genus. $S$. rusylensis differs from $S$. obliqua in having smaller reticulations, with four rows between the median and ventral ridges, whereas $S$. obliqua has two rows, and the muri between these two rows have a tendency to form a weakly defined ridge. However, the two species are very similar, much more so than any other two species, so it seems likely that they are closely related. If this is the case, then S. rusaylensis is possibly the ancestor of S. obliqua.

\section{PALAEOECOLOGY}

Neocyprideis is interpreted as an $r$-selective strategist (Keen, 1990). This means it was adapted to fluctuating environments, where opportunistic species with large, rapidly established populations could thrive, and is therefore typical of either reduced salinities or hypersalinities. It is rare in freshwater or very low salinity deposits, being more abundant in mesohaline or polyhaline conditions. It can form an almost monospecific assemblage in mesohaline or hypersaline conditions, as in this example from Oman. The fact that the associated species belong to typically marine genera rather than brackish or freshwater probably indicates either polyhaline or hypersaline conditions. The very low diversity of the fauna suggests restricted conditions. Such low diversities in ostracod faunas usually rule out polyhaline salinities, so the likelihood is that the fauna is one of a hypersaline environment. This is supported by the occurrence of evaporitic facies within the lower part of the Rusayl Shale and at this level elsewhere in the Arabian Peninsula i.e. in the Rus Formation. The association of Neocyprideis and Stigmatocythere is reported by Siddiqui (1971) from the evaporitic Shales with Alabaster of Pakistan; Siddiqui's accompanying charts also suggest a low diversity fauna.

Euryhaline genera such as Neocyprideis frequently show ecophenotypic characters (Keen 1982). In the case of Neocyprideis these are seen in the ornamentation, which can vary between smooth or punctate, in the development of tubercles, in overall size, and possibly in the shape of the normal pore canals (Keen, 1990). Tuberculate individuals are especially characteristic of salinities below $5 \%$, so the lack of tuberculate adults in the Rusayl Shale fauna suggests the absence of low salinity brackish waters. The size range of adults shows considerable variation: males range between $740-850 \mathrm{~m}$, and females between $760-820 \mathrm{~m}$. This possibly indicates the admixture of many generations which grew under slightly different conditions. 
Rosenfeld \& Vesper (1977) reported a correlation between the shape of the sieve pore and salinity in Cyprideis torosa (Jones 1850), with circular pores characterizing low salinities, oblong pores mesohalinepolyhaline, and irregular pores hypersalinities. The normal pore canals are often well preserved in these Rusayl Shale specimens, and show both circular and irregular pores (Pl. 1, figs 13, 15); this line of evidence is thus inconclusive in differentiating between brackish and hypersaline, although irregular pores are virtually unknown in faunas from Europe where the evidence clearly indicates hyposaline conditions.

The ostracod evidence is in line with that derived from the sediments as given in the description of the Ruseyl Shale, i.e. a restricted supratidal to lagoonal environment.

\section{PALAEOBIOGEOGRAPHY}

Neocyprideis was widely distributed in the Palaeogene, being reported from western Europe, southern Europe, Turkey, Israel, and Pakistan (Keen 1990) and from west Africa (Carbonnel, 1989). Stigmatocythere is also widely distributed, but unlike Neocyprideis, appears to have had biogeographical significance. According to Siddiqui (1983) it is found in the Tertiary of India, Pakistan, Nigeria, Tanzania and South Africa; the Nigerian occurrence however is suspect. Thus its typical distribution is around the shores of the western Indian Ocean. During the Palaeogene these localities were even closer together than they are now, before India reached its northern position in contact with the Eurasian landmass. This distribution is along the southern shores of eastern Tethys.

\section{ACKNOWLEDGEMENTS}

Graham Coles (Geochem Group Limited) is gratefully acknowledged for his constructive criticism of the manuscript.

\section{Manuscript received March 1991 \\ Manuscript accepted August 1991}

\section{REFERENCES}

Al-Furaih, A.A.F. 1980. Upper Cretaceous and Lower Tertiary Ostracoda (Superfamily Cytheracea)from Saudi Arabia. University Libraries, University of Riyadhi, Saudi Arabia, 211pp.

Bassiouni, M.A.A. \& Luger, R. 1990. Maastrichtian to Early Eocene Ostracoda from southern Egypt. Palaeontology, Palaeoecology, Palaeobiogeography and biostratigraphy. Berliner geowiss. Abh., (A), 120, 755-928.

Benson, R.H. 1972. The Bradleya Problem, with descriptions of two new psychrospheric ostracode genera, Agrenocythere and Poseidonamicus (Ostracoda: Crustacea). Smithsonian Contributions to Palaeobiology, 12, 138pp., 14 pls.

Carbonnel, G. 1989. Les Ostracods saumatres des lignites de l'Eocene inferieur au Senegal: point de convergence des flux migratoires. Cour. Forsch.-Inst. Senckenberg, 113, 89-95.

Gaemers, P.A.M. 1978. Systematics of the alveolinids of the Tremp Basin, south-central Pyrenees, Spain. Leid. geol. Meded., 51, 103-129.

Keen, M.C. 1977. Ostracod assemblages and the depositional environments of the Headon, Osborne, and Bembridge Beds (Upper Eocene) of the Hampshire Basin. Palaeontology, 20, 405-445.

Keen, M.C. 1982. Intraspecific variation in Tertiary ostracods, In: Bate, R.H., Robinson, E. \& Sheppard ' L.M. (Eds), Fossil and Recent Ostracods, Ellis Horwood, Chichester, 381-405.

Keen, M.C. 1990. The ecology and evolution of the Palaeogene ostracod Neocyprideis. Cour. Forsch.-Inst. Senckenberg, 123, 217-228.

Neale, J.W. and Singh, P. 1985. Ostracoda from the middle Eocene of Assam. Palaeontology, 28 (2), 355-385.
Reyment, R.A. 1960. Studies on Nigerian Upper Cretaceous and Lower Tertiary Ostracoda: 1, Senonian and Maastrichtian Ostracoda. Stockh. Contr. Geol., 7, 238pp.

Rosenfeld A. \& Vesper, B. 1977. The variability of the sieve pores in Recent and fossil species of Cyprideis torosa (Jones), as an indicator for salinity and palaeosalinity. In: Loffler, H. \& Danielpol, D. (Eds) Aspects of Ecology and Zoogeography of Recent and Fossil Ostracoda, Junk, The Hague, 55-67.

Siddiqui, Q.A. 1971. Early Tertiary Ostracoda of the family Trachyleberididae from West Pakistan, Bull. Brit. Mus. Nat. Hist. (Geology) Supplement 9, 198.

Siddiqui, Q.A. 1983. The biostratigraphic significance of four ostracode genera (Alopocythere, Gyrocythere, Phalcocythere, and Stigmatocythere, in the Early Tertiary of Pakistan, with a note on their paleozoogeography. In: Maddocks, R.F. (Ed.), Applications of Ostracoda, Univ Houston Geosc., 417-428. 